OBSERVATIONS

\title{
Act now against new NHS competition regulations
}

An open letter to the BMA and the Academy of Medical Royal Colleges calls on them to make a joint public statement of opposition to the amended section 75 regulations

Jacky Davis co-chair, NHS Consultants' Association, and consultant radiologist, Whittington Hospital, London, Ian Banks president, Men's Health Forum, David Wrigley general practitioner, Lancashire, Clive Peedell co-chairman, NHS Consultants' Association, and consultant clinical oncologist, James Cook University Hospital, Middlesbrough, Alyson Pollock professor of public health research and policy, Queen Mary, University of London, Klim McPherson visiting professor of public health epidemiology, Nuffield Dept Obstetrics and Gynaecology and Emeritus fellow of New College, University of Oxford, Martin McKee professor of European public health, London School of Hygiene and Tropical Medicine, William L Irving professor and honorary consultant in virology, University of Nottingham and Nottingham University Hospitals NHS Trust, Peter Crome professor, Institute for Social Sciences and Medical School, Keele University and department of primary care and population health, University College London, Trisha Greenhalgh professor, Global Health, Policy and Innovation Unit, Centre for Primary Care and Public Health, Blizard Institute, Barts and The London School of Medicine and Dentistry, Walter Holland Emeritus professor of public health medicine, London School of Economics and Political Science, David Evans professor in health services research (public involvement), Centre for Health and Clinical Research and associate head of department (research and knowledge exchange), Department of Health and Applied Social Sciences, University of the West of England, Alan Maryon-Davis honorary professor of public health, department of Primary Care \& Public Health Sciences, Kings College London School of Medicine, Alan Smyth professor of Child Health, University of Nottingham and co-ordinating editor, Cochrane Cystic Fibrosis and Genetic Disorders Group, Peter Fleming professor and consultant paediatrician, University Hospitals Bristol, Michel Coleman professor of epidemiology and vital statistics, Cancer Research UK Cancer Survival Group and department of non-communicable disease epidemiology, London School of Hygiene and Tropical Medicine, Deborah J Sharp professor of primary health care, Centre for Academic Primary Care, School of Social and Community Medicine, University of Bristol, Peter Whincup professor of epidemiology, University of London, Division of Population Health Sciences and Education, Stuart Logan Cerebra professor of paediatric epidemiology, director, Institute of Health Service Research, and director, NIHR PenCLAHRC, Derek Cook professor of epidemiology, Division of Population Health Sciences and Education, St George's, University of London, Robert Moore professor, School of Sociology and Social Policy, Eleanor Rathbone Building, University of Liverpool, Salman Rawaf professor of public health, Imperial College London, J McEewen Emeritus professor in public health, University of Glasgow, Robert West professor, Cancer Research UK Health Behaviour Research Centre, Department of Epidemiology and Public Health, University College London, John S Yudkin Emeritus professor of medicine, University College London, Aileen Clarke professor of public health and health services research, Warwick Medical School, University of Warwick, Nick Finer honorary professor, National Centre for Cardiovascular Prevention and Outcomes, UCL Institute of Cardiovascular Science, Paola Domizio professor of pathology education, Barts and the London and honorary consultant histopathologist, Barts Health, Clare Bambra director, Wolfson Research Insitute for Health and Wellbeing and professor of public health policy, Department of Geography, Durham University, Anna Jones teaching fellow, Brighton and Sussex medical school., Gene Feder professor of primary health care, Centre For Academic Primary Care, School of Social and Community Medicine, University of Bristol, Alex Scott-Samuel senior clinical lecturer in public health, University of Liverpool, Louise Irvine GP, London, Ajay Sharma consultant paediatrician, London, Mike Fitchett partner, Island health, London, Kambiz Boomla GP, Chrisp Street Health Centre, London, Jonathan Folb consultant microbiologist, Liverpool, Ashish Paul consultant in public health medicine, Cardiff, David McCoy consultant, public health medicine and senior clinical lecturer, Ray Tallis Emeritus professor, geriatric medicine, Manchester, Jilla Burgess-Allen specialty registrar in public health, Matlock, Mark Edwards GP, University Health Service, University of Southampton, 
Jonathon Tomlinson GP, Lawson Practice, London, Deborah Colvin GP, Lawson Practice, London, Jonathan Gore GP, Lawson Practice, London, Kirsten Brown GP, Lawson Practice, London, Sarah Mitchel GP, Lawson Practice, London, Alice Lau GP, Lawson Practice, London, Mel Sayer GP, Statham Grove, London, Leon Clark GP, Statham Grove, London, Ruth Silverman GP, Statham Grove, London, Saul Marmot GP, Bromley by Bow, Daniel Rainbow GP, Stennack Surgery, St Ives , Lucy Carter GP, Well Street Surgery, London, Nick Mann GP, Well Street Surgery, London, Richard Fielding professor of medical psychology in public health, University of Hong Kong, Jane Logan GP, London, Louise Tebboth GP, Bermondsey, London, Natasha Arnold consultant geriatrician, Homerton Hospital, Kate Stobbart GP, Newcastle upon Tyne, Kate Cabot GP, Acton, London, Sarah Finer specialty registrar and clinical lecturer in diabetes and endocrinology, Barts Health, Martin Edwards GP, Jenner Practice, London, David Davies Amwell Group Practice, London, Helen Buttivant public health specialty registrar, Wessex Deanery, Sebastian Kraemer honorary consultant, Tavistock Clinic and consultant psychiatrist, Paediatric Department, Whittington Hospital, Jo Newell GP, Leeds, Alun Griffiths GP partner, Horton Park Practice, Bradford, Richard FitzGerald consultant radiologist, Wolverhampton, Robert MacGibbon retired GP, London, Alan Lee Nottingham, A F Macklon consultant physician, County Durham and Darlington Foundation Trust, Esther Hobson neuromedicine registrar, Sheffield, David Jenner GP, Cullompton, Bobbie Jacobson public health consultant, Alison Timmis consultant paediatrician, Countess of Chester Hospital NHS Foundation Trust, Asad Salim consultant dermatologist, Countess of Chester NHS Foundation Trust, John Evans-Jones consultant in genitourinary medicine and HIV, Integrated Contraception and Sexual Health Service, Countess of Chester Hospital NHS Foundation Trust, Woody Caan professorial fellow of the Royal Society for Public Health, Cambridge, Ninaad Awsare consultant urological surgeon, Countess of Chester Hospital NHS Foundation Trust, Wirral University Teaching Hospital NHS Foundation Trust, Neil Pride Emeritus professor of respiratory medicine, Imperial College, London, Ruth Suckling specialist registrar, emergency medicine, Catherine Bratty GP, Surrey, Brian Rossiter retired physician, David Hawkins consultant physician, London, Jonny Currie University Hospitals, Bristol, Corinne Camilleri-Ferrante Nottingham , Jonathan Fluxman Harrow Road Health Centre, Osman Bhatti GP principal, Chrisp Street Health Centre, James Anson clinical director and consultant microbiologist, Directorate of Infection and Immunity, Royal Liverpool and Broadgreen University Hospitals NHS Trust, Robert Etherington consultant radiologist, Countess of Chester Hospital, David Lawrence consultant in public health medicine for IFRs, NHS SE London and honorary senior lecturer, Department of Health Services Research and Policy, London School of Hygiene and Tropical Medicine, Henry Fell retired consultant microbiologist, Bury St Edmunds, Edward Clarke GP, Liverpool, Julian Ormerod Great Western Hospital, Swindon, Oliver Ormerod cardiologist, John Radcliffe Hospital, Oxford, Maggie Ireland public health doctor, North East, John A T Duncan retired consultant anaesthetist, Fife, Rajiv Chandy consultant gastroenterologist, St Helens and Knowsley NHS Trust, Jennifer Mindell clinical senior lecturer, Health and Social Surveys Research Group, Research Department of Epidemiology and Public Health, UCL, Paul Mullen Penny Lane Surgery, Phillip Bennett-Richards GP, Aberfeldy Practice, Tower Hamlets, Julie Hirst public health principal, Derbyshire, E Murphy GP, Bristol, P Martin Queens Road Partnership, London, Simon Lowes radiology specialty registrar, Newcastle upon Tyne, Peter Fleming professor and consultant paediatrician, University Hospitals Bristol, Richard Grunewald consultant neurologist and secondary care representative on Hull CCG, Joanne Reeve GP, Liverpool, Martin Schweiger consultant in communicable disease control, Leeds, Jonathan Coates GP registrar, Newcastle, George Farrelly GP, The Tredegar Practice, London, M A Chamberlain professor, rehabilitation medicine, Leeds (retired), Geoffrey Lewis consultant cardiac anaesthetist, Leicester (retired), Jane Young consultant radiologist, London, Brian Scott Emeritus consultant physician, Lincoln, John Gibbs paediatrician, Chester, Aileen Landers staff grade ophthalmologist, Kingston Hospital NHS Trust, Pete Deveson GP, Epsom, Grant Ingrams The Crossley Practice, Coventry, Martha Leigh GP, Wapping Health Centre, London, Jeff Gawler retired neurologist, Amy Ford specialty registrar, Clatterbridge Oncology Centre, Jonathan Nixon St Andrews, Fife, Margaret McCartney GP, Glasgow, David Bareford Worcester, Surinder Singh GP and senior lecturer in general practice, UCL, Kate Lockwood doctor, Michael Cripwell GP, Islington., Peter Ehrhardt consultant paediatrician, Leeds, David Bell consultant psychiatrist, Tavistock and Potman NHS Foundation Trust, Pam Wortley retired GP, Sunderland, Laurie Tomlinson honorary consultant, Addenbrookes Hospital, Julie Hotchkiss Ashton, Leigh and Wigan Primary Care Trust, Steven Ford retired GP, Haydon Bridge, Gill Turner consultant paediatrician, West Northumberland, Hexham General Hospital, Gerard Reissman GP, Newcastle, David Lewis general practitioner, Vauxhall Primary Heath Care, Chris Johnstone GP, Paisley, Mike Tomson GP and trainer, Mathews Practice, Sheffield, Payam Torabi SHO (GP VTS), department of clinical gerontology, King's College Hospital, David Bell London, D Tomson freelance consultant in patient centred care, Alex Tulloch senior clinical researcher, Health Services and Population Research Department, Institute of Psychiatry, King's College London, Sally Johnston GP, Hampshire, Jane Dickinson Newcastle, Elisabeth McElderry GP, Devon, Wendy Ross GP, Newcastle, Kim Holt consultant paediatrician, London, Mary Logan GP locum, Enfield and Waltham Forest, Hilary Klonin consultant paediatric intensivist, Hull, David Jenner GP, Cullompton, Jude Danby NHS GP, Bradford, V Goodger GP principal, Hereford, John Puntis consultant 
paediatrician, General Infirmary at Leeds, Harriet Dickson GP, Exeter, Derek A Gould professor and consultant radiologist, Royal Liverpool NHS Trust, Anna Livingstone GP, Limehouse Practice, London, Dianne Lefevre psychotherapist, Basildon, Bryony Kendall Aintree Park Group Practice, Liverpool, G Singh Rosebery Medical Practice, Loughborough, Peter Hall chair, Doctors for Human Rights, Jonathan Darling senior lecturer and honorary consultant in paediatrics and child health, Academic Unit of Paediatrics and Obstetrics and Gynaecology, Leeds Institute of Medical Education, Adrian N Hamlyn consultant physician, Dudley, Anita Patel Barnet, Jonathan Erskine research associate, Centre for Public Policy and Health, School for Medicine, Pharmacy and Health, Durham University, Brian Fisher GP, London, Richard Hughes professor, London, Clare Highton chair, City and Hackney CCG, Helen Venning retired consultant paediatrician, Grantham, Lincs, Ron Singer President, Medical Practioners' Union-Unite, Steve Brearey consultant paediatrician, Countess of Chester Foundation NHS Trust, Jim Sikorski Sydenham Green Group Practice, London, David Paintin Emeritus reader in obstetrics and gynaecology, Imperial College School of Medicine at St Mary's, London, John Feehally professor and consultant nephrologist, University Hospitals of Leicester, professor of renal medicine, University of Leicester, and president, International Society of Nephrology, Wendy Savage professor, London, Kathy McAdam Freud GP principal, London, Victoria J Holt GP lead, urgent care, Homerton University Hospital, London, Alison Gill respiratory ST6 doctor, Leeds, Tony Waterston retired consultant paediatrician, Newcastle upon Tyne, Richard de Souza GP, Portslade, Brighton and Hove, Nicholas Hopkinson consultant chest physician, London, Mike Beadsworth consultant in infectious diseases, tropical medicine, and clinical pharmacology, Liverpool, Andrea Franks consultant dermatologist, Chester, Helen Daley consultant community paediatrician, Child Health Services, Fareham, Paul Cullinan professor in occupational and environmental respiratory disease, Imperial College (NHLI) and Royal Brompton Hospital, London, Adriana Basarab consultant, Department of Infection, University Hospital Southampton NHS Foundation Trust, Southampton, Jonathan Folb consultant microbiologist, Liverpool, Hugh Gurling professor of molecular psychiatry and honorary consultant psychiatrist, Mental Health Sciences Unit, University College London, Pam Zinkin London, Simon Kirwin specialist registrar in liaison psychiatry, London, Ernst Buhrs GP, Liverpool, Raymond Brown consultant paediatrician, Andrew West consultant child and adolescent psychiatrist, Reading CAMHS and PPALS, Gary Marlowe GP, de Beauvoir Surgery, London, , Griffith Fellows retired urologist, John Main consultant nephrologist, South Tees Acute Hospitals NHS Trust, Jackie Applebee GP, London, M Koperski PEC chair, Camden, London, Phil Jones consultant intensivist and cardiothoracic anaesthetist, St Bartholomew's Hospital, London, Alison Macfarlane School of Health Sciences, City University London, London, Naomi Beer GP, Jubilee Street Practice, London, Rebecca Mason specialty registrar in public health (ST3), Mersey Deanery, Robert West emeritus professor of epidemiology, Wales Heart Research Institute, Cardiff University, Maggie Eisner training programme director, Bradford Specialist Training Scheme for General Practice, Alison Smailes GP, Tower Hamlets, London, Philip Timms consultant psychiatrist, START homeless team; honorary senior lecturer, King's College London; Psychosis Clinical Academic Group (Recovery), South London and Maudsley NHS Foundation Trust, David Knight Barnabas Medical Centre, Northolt, Coral Jones GP, London, Barbara Wesby retired GP, Lambeth, London, Laura Lyttelton GP examiner and appraiser, Hackney, London, Richard Morrison retired GP, David Bossano St Leonards Practice, Exeter, Jonathan Walker consultant in critical care and anaesthesia, Royal Liverpool University and Broadgreen Hospitals NHS Trust, Liverpool, Gerry Davies senior lecturer in infection pharmacology, Institutes of Global Health and Translational Medicine, Peter Godfrey GP locum, Devon, Ingrid Wolfe child public health research fellow, London School of Hygiene and Tropical Medicine, London, Emmanuel Nsutebu consultant infectious diseases physician, Royal Liverpool Hospital, Nicola Stevenson consultant chest physician, Wirral Hospital, Sheila Cheeroth Limehouse Practice, Gill Street Health Centre, London, Jo Miller GP, Huddersfield, Guy Johnson Edinburgh, R Noor GP, North London, Alyson Hall honorary consultant child and adolescent psychiatrist, East London Foundation NHS Trust., David Bostock 14 Davenport Park Road, Stockport, Benedict Michael NIHR doctoral research fellow, Institute for Infection and Global Health, University of Liverpool, John Sharvill GP, Balmoral Surgery, Deal, Kent, Jamie Macpherson GP, Coventry, David Lewis GP, Watford, Richard Ma GP, London, John Middleton, director of public health, West Midlands, Anne Jeffreys salaried GP, chair of East Yorkshire and Humberside LMC, Jim Cole GP, London, John P Boswell public health specialist, Stirlingshire, Scotland, Bob Bury consultant radiologist, Leeds, Sally Mitchison retired consultant psychiatrist, Sunderland, Ann-Louise Kinmonth emeritus professor of general practice, University of Cambridge, Gail Young retired GP, Newcastle upon Tyne, lain Maclennan doctor, Pat Munday retired consultant genitourinary physician, Flaunden 
On 1 April the government is due to enact enabling legislation to the Health and Social Care Act, which will in effect require clinical commissioning groups to enter into competitive tendering for all NHS services. This contradicts clear promises made in the letter that former health secretary Andrew Lansley sent to clinical commissioning groups on 16 February 2012, which stated "it is a fundamental principle of the Bill that you as commissioners should decide when and how competition should be used to serve your patients' interests."1

The original section 75 proposals were withdrawn after widespread protests. Amended regulations were tabled, but there is widespread consensus (including Counsel's opinion) that these do not change the underlying thrust. The amended regulations state that commissioners are not required to advertise if "satisfied" that the services can be provided by a single provider only. However, there remains the strong possibility that a decision not to tender will be challenged by a dissatisfied commercial provider, threatening to involve the clinical commissioning group in lengthy and expensive litigation. The only way a commissioning group can prove that services can be provided by a single provider only is to go to tender. Groups are therefore likely to practise "defensive tendering"- that is, tendering to protect themselves from risk of litigation from private providers. This would waste public money, and "wasteful" tendering could itself breach regulation 2 (for inefficiency).

Forcing clinical commissioning groups to practise competitive tendering will not only break government promises made about the autonomy of these groups, but it will also lead to inevitable acceleration of the privatisation of the NHS, which is already under way. While the government has repeatedly insisted that it will not privatise the NHS, what is happening now meets all criteria for the definition, including the criteria of the World Health Organization. ${ }^{2}$ It is part of a wave of healthcare system privatisation forced on European Union countries by Washington's requirement for legal harmonisation with US laws before the EU-US treaty that David Cameron will sign in June 2013. The rhetoric of these reforms is "the best interest of the patients," but the reality is a raid on public service budgets and an attempt to open the door to co-payments and the expansion of private health insurance.

In its response to the Future Forum report ${ }^{3}$ the government specifically undertook to rule out privatisation of the NHS. Health minister Simon Burns promised in a letter, "We will never 'privatise' the NHS, will never pursue competition as an end in itself, and frontline staff (will have) the ability to take control of the services they can offer." Deputy Prime Minister
Nick Clegg promised, "Yes to reform of the NHS—but no to the privatisation of the NHS." The content of the section 75 regulations shows these statements were not and cannot be true. They are a classic set of privatisation regulations. Many countries have already been caught in the trap set by these regulations and are seeing healthcare costs climb and outcomes deteriorate-let us not follow them into an avoidable healthcare disaster.

Promises made to the profession and the public are now seen to mean nothing and full opposition to these regulations is the only possible response. Doctors are trusted by patients and the public and thus we have a duty to speak out when acts of vandalism are perpetrated on the health service we all work in and on which our patients and families rely.

We are appealing to the elected leaders of the medical profession to stand up and be counted at this last hour. Once again the future of the NHS is in your hands. We call upon the BMA and the Academy of Medical Royal Colleges to make a joint public statement of opposition to the amended section 75 regulations. It is not too late to change the direction of travel that the government is pursuing against the wishes of the profession and the public, and which these regulations will cement in place. Please act now.

Competing interests: JD, IB, DW, and CP have read and understood the BMJ Group policy on declaration of interests and declare the following interests: JD and CP are co-chairs of the NHS Consultants Association, a pressure group that believes the NHS should remain a publicly funded, publicly provided, and publicly accountable healthcare system. CP is co-leader and JD is on the national executive committee of the National Health Action Party, a new political party set up by healthcare professionals who oppose the increasing marketisation and privatisation of the NHS in England. JD is a founder member of Keep Our NHS Public, a campaigning organisation for a publicly funded, publicly delivered, and publicly accountable NHS.

Provenance and peer review: Not commissioned; not externally peer reviewed.

1 http://falseeconomy.org.uk/files/lansley-ccg.pdf.

2 www.healthprofessionals4nhs.co.uk/wp-content/uploads/2012/01/Peedell-privatisationis-inevitable-bmj.d2996.full_.pdf.

3 www.dh.gov.uk/prod_consum_dh/groups/dh_digitalassets/documents/digitalasset/dh_ 127719.pdf.

4 www.independent.co.uk/voices/letters/letters-1000-more-doctors-join-call-to-reject-nhsbill-2369043.html.

Cite this as: BMJ 2013;346:f1819

๑ BMJ Publishing Group Ltd 2013 